This is an electronic reprint of the original article. This reprint may differ from the original in pagination and typographic detail.

Author(s): Rekken, Brian; Brown, Thomas; Fettinger, James; Tuononen, Heikki; Power, Philip

Title: $\quad$ Isolation of a Stable, Acyclic, Two-Coordinate Silylene

Year: $\quad 2012$

Version:

Please cite the original version:

Rekken, B., Brown, T., Fettinger, J., Tuononen, H., \& Power, P. (2012). Isolation of a Stable, Acyclic, Two-Coordinate Silylene. Journal of the American Chemical Society, 134(15), 6504-6507. https://doi.org/10.1021/ja301091v

All material supplied via JYX is protected by copyright and other intellectual property rights, and duplication or sale of all or part of any of the repository collections is not permitted, except that material may be duplicated by you for your research use or educational purposes in electronic or print form. You must obtain permission for any other use. Electronic or print copies may not be offered, whether for sale or otherwise to anyone who is not an authorised user. 


\title{
Isolation of a Stable, Acyclic, Two-Coordinate Silylene
}

\author{
Brian D. Rekken,, Thomas M. Brown, + James C. Fettinger, + Heikki M. Tuononen, ${ }^{*}$ Philip P. Power ${ }^{*+}$ \\ +Department of Chemistry, University of California, Davis, One Shields Avenue, Davis, California, 95616, USA; \\ ₹Department of Chemistry, University of Jyväskylä, P.O. Box 35, FI-40014 Jyväskylä, Finland
}

\begin{abstract}
The synthesis and characterization of a stable, acyclic two-coordinate silylene, $\mathrm{Si}\left(\mathrm{SAr}^{\mathrm{Me}} 6\right)_{2}$, $\left(\mathrm{Ar}^{\mathrm{Me}_{6}}=\mathrm{C}_{6} \mathrm{H}_{3}-2,6\left(\mathrm{C}_{6} \mathrm{H}_{2}-2,4,6-\mathrm{Me}_{3}\right)_{2}\right)$ by reduction of

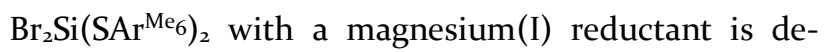
scribed. It features a v-shaped silicon coordination with a S-Si-S angle of $90.519(2)^{\circ}$ and an average Si-S distance of $2.158(3) \AA$. Although it reacts readily with an alkyl halide, it does not react with hydrogen under ambient conditions probably as a result of the $c a .4 .3$ $\mathrm{eV}$ energy difference between the frontier silicon lone pair and 3p orbitals.
\end{abstract}

For several decades, silylenes, the silicon analogues of carbenes, had been known only as transient species either in the gas phase, in solution, or trapped in frozen matrices. ${ }^{1,2}$, 3 In 1986, however, Jutzi and coworkers reported the isolation of decamethylsilicocene which was the first monomeric, divalent silicon(II) compound that was stable at room temperature. ${ }^{4}$ The formally tencoordinate $\mathrm{Si}\left(\eta^{5}-\mathrm{C}_{5} \mathrm{Me}_{5}\right)_{2}$ exists as two conformers; a centrosymmetric species with parallel $\mathrm{C}_{5} \mathrm{Me}_{5}$ rings or a bent form with a $25.3^{\circ}$ interplanar angle. In 1994, the synthesis and structure of a two-coordinate, Nheterocyclic silylene, in which silicon is single bonded to two nitrogens, was reported by West and coworkers. ${ }^{5}$ Currently, numerous stable divalent silicon species are known ${ }^{2,6-8}$ but strictly two-coordinate species invariably involve silicon as part of a ring ${ }^{9}$ with the most common being the aforementioned N-heterocyclic silylenes. ${ }^{10} \mathrm{~A}$ cyclic alkyl silylene, which is stable at $\mathrm{o}{ }^{\circ} \mathrm{C}$, was reported by Kira but it isomerizes in solution via a 1,2-migration of an adjacent trimethylsilyl group to give a silene. ${ }^{11}$ Other examples include the bisamido derivative $\mathrm{Si}\left(\mathrm{NPr}_{2}{ }_{2}\right)_{2}$ which exists in a monomer/dimer equilibrium with the SiSi double-bonded disilene $\left\{\mathrm{Si}\left(\mathrm{NPr}_{2}^{\mathrm{i}}\right)_{2}\right\}_{2},{ }^{12}$ as well as $\mathrm{Si}\left\{\mathrm{N}\left(\mathrm{SiMe}_{3}\right)_{2}\right\}_{2}$, which persists for more than 12 $\mathrm{h}$ at $-20{ }^{\circ} \mathrm{C}$ but decomposes into a complex mixture of products at increased temperatures. ${ }^{13}$ We now report that the reduction of the silicon(IV) precursor,

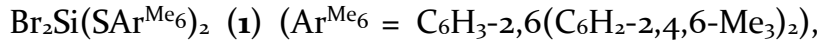
affords the silicon dithiolate, $\mathrm{Si}\left(\mathrm{SAr}^{\mathrm{Me}}\right)_{2}(2)$, which has a monomeric, two-coordinate structure and is an example of a stable acyclic two-coordinate silylene. In addition, the $\mathrm{Si}(\mathrm{IV})$ bisthiolatosilane 3 was prepared in order to compare its structural and spectroscopic pa- rameters with those of $\mathbf{2}$. Furthermore, 2 was characterized by its derivatization with MeI to afford $\mathrm{Si}(\mathrm{Me})(\mathrm{I})\left(\mathrm{SAr}^{\mathrm{Me}}\right)_{2}(4)$. An overview of the synthesis is given in Scheme 1.

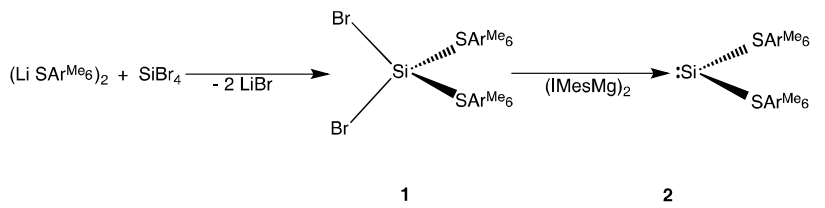

Scheme 1. Synthesis of Silylene $\mathbf{2}$ by Reduction of $\mathbf{1 .}$

The precursor, $\mathbf{1}$, was obtained by reaction of $\mathrm{SiBr}_{4}$ with ( $\left.\mathrm{LiSAr}^{\mathrm{Me}_{6}}\right)_{2}$ in diethyl ether. ${ }^{1,15}$ and 2 was synthesized by reduction with Jones' complex (IMesMg) (IMes $\left.=\left[(2,4,6 \text {-trimethylphenyl }) \mathrm{NC}\left(\mathrm{CH}_{3}\right)\right]_{2} \mathrm{CH}\right)$ complex in toluene. ${ }^{16,17}$ The yellow solution of $\mathrm{Br}_{2} \mathrm{Si}(\mathrm{SAr}$ $\left.\mathrm{Me}_{6}\right)_{2}$ became darker with concomitant precipitation of IMesMgBr, upon stirring for 2 days at ca. $25^{\circ} \mathrm{C}$. Workup afforded colorless crystals of 2 in moderate yield (51\%). The silylene, $\mathbf{2}$, was found to be stable up to $146^{\circ} \mathrm{C}$. The $\mathrm{X}$-ray crystal structure of $\mathbf{2}$ (Figure 1 ) showed that the silicon bonds to two thiolate sulfurs with a S-Si-S angle of $90.52(19)^{\circ}$. The Si-S distances are 2.1607(5) and 2.1560(5) $\AA$ and the Si-S-C angles are 100.85(5) and $105.01(4)^{\circ}$. The closest other approaches to silicon involve $C(7)$ and $C(12)$ at 3.004(1) and 3.232(1) $\AA$ as well as $\mathrm{C}(31)$ and $\mathrm{C}(32)$ at 3.052(1) and 3.293(1) $\AA$ respectively. The Si-centroid distances to the rings are 3.453 and $3 \cdot 419 \AA$ A.

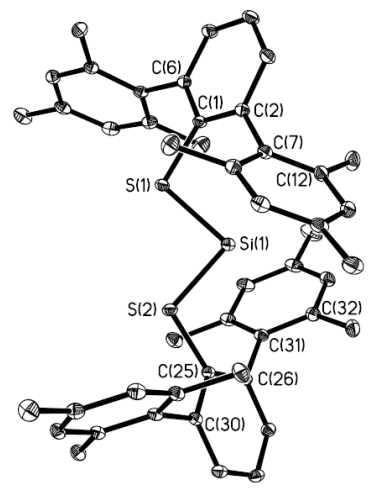

Figure 1. Thermal ellipsoid (30\%) plot of 2 without $\mathrm{H}$ atoms. Selected bond lengths $(\AA ̊)$ and angles $\left(^{\circ}\right)$ : $\operatorname{Si}(1)$ - 
$\mathrm{S}(1) 2.1607(5), \mathrm{Si}(1)-\mathrm{S}(2) \quad 2.1560(5), \mathrm{S}(1)-\mathrm{C}(1)$ 1.7916(13), $\mathrm{S}(2)-\mathrm{C}(25) \quad 1.7902(13), \quad \mathrm{Si}(1)$-Centroid(1) 3.453, $\mathrm{Si}(1)$ Centroid(2) 3.419, S(1)-Si(1)-S(2) 90.519(19), C(1)-S(1)$\mathrm{Si}(1) 100.85(5), \mathrm{C}(25)-\mathrm{S}(2)-\mathrm{Si}(1) 105.01(4)$.

The Si-S bonds are mainly single in character as indicated by the calculated WBI of 0.95 for the Si-S bonds ${ }^{18}$ although weak $\mathrm{Si}-\mathrm{S} \pi$-bonding may exist as indicated by computations (vide infra) and the low average torsion angle $\left(13.4(2.1)^{\circ}\right)$ between the coordination plane of silicon and those at the sulfurs. ${ }^{7 a, 19,20}$ The Si-S distances in $\mathbf{2}$ are longer than those reported for in the bisthiolatosilylene- platinum complex, trans$\left(\mathrm{Cy}_{3} \mathrm{P}\right)_{2} \mathrm{Pt}(\mathrm{H}) \mathrm{Si}(\mathrm{SEt})_{2} \mathrm{OTf}$, by ca. $0.07 \AA{ }^{7 \mathrm{a}}$ but are comparable to those predicted for 1,2-ethanedisulfide silylene. ${ }^{20}$ DFT Calculations, ${ }^{21}$ using the hybrid PBE1PBE exchange-correlation functional ${ }^{22}$ in combination with the def2-TZVP basis set for the whole molecule of $\mathbf{2}$ and $3^{23}$ afforded structural parameters very close to those experimentally measured (Table 1 ).

The ${ }^{29} \mathrm{Si}$ NMR spectrum of $\mathbf{2}$ revealed a downfield signal at $\delta=285.5$ (cf. $\delta=-23.1$ for $\mathbf{1}$ ). The signal is further downfield than those of cyclic amidosilylenes $(\delta=$ 78-119), ${ }^{5,10}$ Driess' ylide-stabilized silylenes $(\delta=212.4$, 213.3 $)^{17}$ and the thermally unstable silylene, $\mathrm{Si}\left\{\mathrm{N}\left(\mathrm{SiMe}_{3}\right)_{2}\right\}_{2}(\delta=223.9) ;^{13}$ however, it is well upfield that reported for the dialkylsilylene $(\delta=567) .{ }^{11}$ The downfield shift of $\mathbf{2}$ is consistent with a two-coordinate silicon since an increased coordination number produces a significant upfield shift as observed in $\left(\mathrm{C}_{6} \mathrm{H}_{3}-\right.$ $\left.2,6\left(\mathrm{C}_{6} \mathrm{H}_{2}-2,4,6-\mathrm{Pr}_{3}{ }_{3}\right)_{2}\right) \mathrm{Si}\left(\eta^{5}-\mathrm{C}_{5} \mathrm{Me}_{5}\right)(\delta=51.6)$ (four coordinate silicon $)^{24}$ and decamethylsilicocene $(\delta=-577)$ (ten coordinate silicon).4,25 The ${ }^{1} \mathrm{H}$ and ${ }^{13} \mathrm{C}$ NMR spectra suggest free-rotation around the $\mathrm{C}-\mathrm{S}$ bond due to the observation of only two signals for the $o$ - and $p$ - methyl groups of the flanking arene rings.

Table 1. Selected Bond Lengths $(\AA)$ and Angles $\left(^{\circ}\right)$ for the Experimental and Calculated Structural Data for 1-3

\begin{tabular}{llllll} 
& \multicolumn{1}{c}{$\mathbf{1}$} & \multicolumn{1}{c}{$\mathbf{2}$} & & \multicolumn{2}{c}{3} \\
& exptl & exptl & calcd & exptl & calcd \\
Si-S & $2.113(1)$ & $2.158(3)^{*}$ & 2.153 & $2.139(1)^{*}$ & 2.143 \\
S-C & $1.791(2)^{*}$ & $1.791(2)^{*}$ & 1.775 & $1.787(3)^{*}$ & 1.778 \\
Si- & $4.42^{*}$ & $3.431^{*}$ & 3.606 & $3.546^{*}$ & 3.649 \\
Centroid & & & & & \\
S-Si-S & $100.05(2)$ & $90.52(2)$ & 90.04 & $93.5(0.9)^{*}$ & 95.74 \\
C-S-Si & $110.44(8)^{*}$ & $102.9(2.1)^{*}$ & 104.36 & $107.8(1.5)^{*}$ & 107.05 \\
* Average. & & & & &
\end{tabular}

The electronic transitions were calculated by the TD-DFT approach using the same functional-basis set combination as employed in the geometry optimization. ${ }^{21-23}$ The Kohn-Sham orbitals for $\mathbf{2}$ are shown in Figure 2. The calculations reveal several excitations at wavelengths between $250-400 \mathrm{~nm}$ although only the five strongest predicted absorptions are discussed here. The calculated values may be compared to the four transitions observed in the electronic spectrum. The HOMO-LUMO (silicon $\mathrm{n} \rightarrow 3 \mathrm{p}$ ) absorption appears as a shoulder at $382 \mathrm{~nm}\left(\varepsilon=8300 \mathrm{M}^{-1} \mathrm{~cm}^{-1}\right){ }^{26}$ A more intense absorption at $318 \mathrm{~nm}\left(\varepsilon=23,000 \mathrm{M}^{-1} \mathrm{~cm}^{-1}\right)\left(\mathrm{HOMO}_{-1} \rightarrow\right.$ LUMO) corresponds to a transition from a sulfur lone pair to the silicon 3p orbital. The calculated absorption at $296 \mathrm{~nm}$ corresponds to the HOMO $\rightarrow$ LUMO+1 transition but is partly obscured by other absorptions that are close in energy. It arises from transitions between the silicon lone pair to the arene $\pi^{*}$ orbitals. The absorptions at $291\left(\varepsilon=20,000 \mathrm{M}^{-1} \mathrm{~cm}^{-1}\right)$ and $269(\varepsilon=25,000$ $\left.\mathrm{M}^{-1} \mathrm{~cm}^{-1}\right) \mathrm{nm}$ are due to an arene $\pi$ to silicon p transition and from both silicon and sulfur lone pairs to arene $\pi^{*}$ orbitals respectively. A series of very intense absorptions, centered at ca. $220 \mathrm{~nm}$, correspond to arene $\pi \rightarrow$ $\pi^{*}$ transitions that partially mask the absorptions at 291 and $269 \mathrm{~nm}$. Overall, the experimental and computational values for the spectral data are in good agreement (associated content).

The bisthiolatosilane, 3, (Figure 3) was obtained from $\mathrm{H}_{2} \mathrm{SiCl}_{2}$ and $\left(\mathrm{LiSAr}^{\mathrm{Me}}\right)_{2}$. The structural data reveal a relatively close resemblance between the structural parameters for the $\mathrm{Si}[\mathrm{S}(\mathrm{C}-i p s o)]_{2}$ moiety and those of silylene 2, with very similar Si-S distances and a small, ca. $3^{\circ}$, difference in the S-Si-S bond angle. The Sicentroid distances differ by ca. o.11 $\mathrm{A}$. However, the compounds 2 and 3 were unequivocally distinguished by the location and refinement of the two Si-H hydrogens in 3. The presence of the $\mathrm{Si}-\mathrm{H}$ hydrogens was also confirmed by the observation of a 1:2:1 triplet signal in the ${ }^{29} \mathrm{Si}$ NMR spectrum at $\delta=-13.22$ ( $\left.{ }^{1} \mathrm{~S} \mathrm{SiH}=256 \mathrm{~Hz}.\right){ }^{27}$ In addition, the $\mathrm{Si}-\mathrm{H}$ signal in the ${ }^{1} \mathrm{H}$ NMR spectrum was observed at $4.11 \mathrm{ppm}$ and two satellite signals corresponding to the natural abundance of ${ }^{29} \mathrm{Si}$ were also identified ( $\left.{ }^{(} \mathrm{J} \mathrm{SiH}=256 \mathrm{~Hz}\right)$. Two partially overlapped absorptions at 2182 and $2168 \mathrm{~cm}^{-1}$ in the IR spectrum are characteristic of a and $\mathrm{b} \mathrm{Si}-\mathrm{H}$ stretching modes. ${ }^{27,28}$

The addition of MeI to 2 afforded the iodo-methylbisthiolatosilane, $4^{6,29}$ Its ${ }^{29} \mathrm{Si}$ NMR spectrum revealed an upfield quartet at $\delta=-5.88\left({ }^{2} \mathrm{~J} \mathrm{SiH}=8.3 \mathrm{~Hz}\right)$ A methyl group signal at $\delta=2.01\left({ }^{2} \mathrm{JSiH}=8.7 \mathrm{~Hz}\right)$ in the ${ }^{1} \mathrm{H}$ NMR spectrum and a signal at $\delta=11.39$ in the ${ }^{13} \mathrm{C}$ NMR spectrum is comparable to compounds with similar moieties. $^{30,31}$

Attempts to react $\mathbf{2}$ directly with hydrogen gas to afford 3 were unsuccessful, possibly because of the relatively high electronegativity of the thiolate substituents which increase the energy separation $(4.26 \mathrm{eV})$ of the silicon lone pair and the $3 p$ orbitals and make the synergic interaction between the frontier orbitals of $\mathbf{2}$ and $\mathrm{H}_{2}$ less likely. In effect, the electronegative character of the thiolate ligands is a key factor both in the stability of 2 (with some help from Si-S $\pi$-bonding), and its reluctance to react with hydrogen. Geometric constraints of the ligands may also hinder the reactivity of $\mathbf{2 .} .^{32}$ 


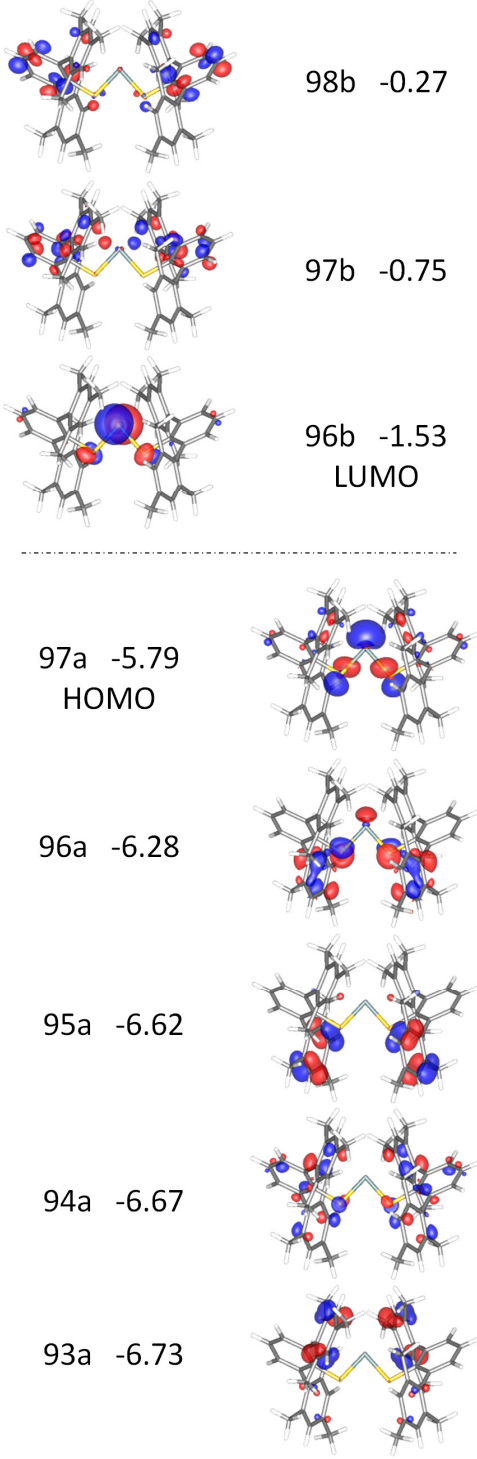

Figure 2. Kohn-Sham molecular orbitals for 2 (orbital energies are given in $\mathrm{eV}$ ).

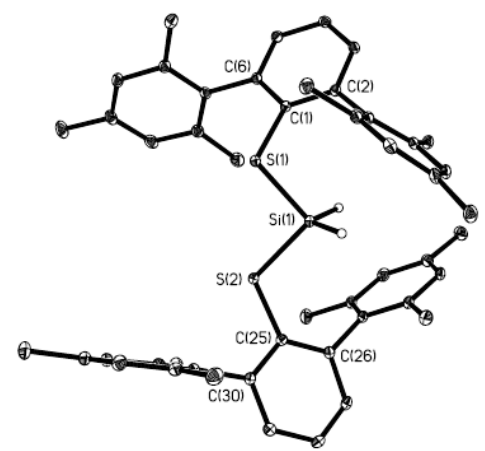

Figure 3. Thermal ellipsoid (30\%) drawing of one of the crystallographically independent molecules of 3. Selected bond lengths $(\AA)$ and angles $\left({ }^{\circ}\right)$ : $\operatorname{Si}(1)-\mathrm{S}(1)$ 2.1372(6), $\mathrm{Si}(1)-\mathrm{S}(2)$ 2.1403(6), $\mathrm{S}(1)-\mathrm{C}(1)$ 1.7859(15), $\mathrm{S}(2)-$ C(25) $1.7892(16), \quad \mathrm{Si}(1)$-Centroid(1) 3.500, $\quad \mathrm{Si}(1)$ Centroid(2) 3.591, S(1)-Si(1)-S(2) 94.41(2), C(1)-S(1)-Si(1) 104.97(5), C(25)-S(2)-Si(1) 108.79(5).
In summary, a thermally stable, two-coordinate, acyclic silylene stabilized by a bulky terphenyl thiolate ligand has been synthesized and characterized. Until now, stable two-coordinate silylenes have been limited to cyclic systems in which silicon is bound to elements of the $2^{\text {nd }}$ row of the periodic table. Future work will involve the investigation of further reactions of $\mathbf{2}$ as well as those of its heavier element analogues.

Note: The synthesis and structure of another type of acyclic silylene is given in the preceding paper. ${ }^{33}$

\section{ASSOCIATED CONTENT}

\section{Supporting Information}

Crystallographic information files for 1-3. Experimental details and ${ }^{1} \mathrm{H},{ }^{13} \mathrm{C}$ and ${ }^{29} \mathrm{Si}$ NMR spectra for $\mathbf{1 - 4}$, infrared spectra of 2 and 3, UV-Vis spectrum and table of the experimental and calculated electronic spectra of $\mathbf{2}$, computational results on the models of compounds 2 and 3, tables of crystallographic data for 1-3 (PDF/CIF). This material is available free of charge via the Internet at http://pubs.acs.org.

\section{Corresponding Author}

power@chem.ucdavis.edu, heikki.m.tuononen@jyu.fi

\section{Acknowledgements}

We are grateful to the U.S. National Science Foundation (CHE - 09848417), the Academy of Finland, University of Jyväskylä, and the Technology Industries of Finland Centennial Foundation Fund for financial support.

\section{REFERENCES}

1. Bürger, H.; Eujen, R. Top. Curr. Chem. 1974, 50, 1-41.

2. Silylene reviews: (a) Lee, V. Y.; Sekiguchi, A. Organometallic Compounds of Low-Coordinate Si, Ge, Sn and Pb: From Phantom Species to Stable Compounds; John Wiley \& Sons Ltd: Chichester, UK, 2010; 139-188; (b) Karni, M.; Kapp, J.; Schleyer, P. v. R.; Apeloig, Y., The chemistry of organic silicon compounds, Vol. 3; Rappoport, Z., Apeloig, Y., Eds; John Wiley \& Sons, Ltd: Chichester, U.K., 2001, p 1; (c) Mizuhata, Y.; Sasamori, S.; Tokitoh, N. J. Am. Chem. Soc., 2009, 109, 3479-3511.

3. Work on transient silylenes also includes species with triplet ground states. See, Sekiguchi, A.; Tanaka, T.; Ichinohe, M.; Akiyama, K.; Tero-Kubota, S. J. Am. Chem. Soc. 2003, 125, 4962-4964.

4. (a) Jutzi, P.; Kanne, D.; Krüger, C. Angew. Chem. 1986, 98, 163; Angew. Chem. Int. Ed. Engl. 1986, 25, 164. (b) Jutzi, P.; Holtmann, U.; Kanne, D.; Krüger, C.; Blom, R.; Gleiter, R.; Hyla-Kryspin, I. Chem. Ber. 1989, 122, 1629-1639. 
5. Denk, M.; Lennon, R.; Hayashi, R.; West, R.; Belyakov, A. V.; Verne, H. P.; Haaland, A.; Wagner, M.; Metzler, N. J. Am. Chem. Soc. 1994, 116, 2691-2692.

6. Haaf, M.; Schmedake, T. A.; West, R. Acc. Chem. Res. 2001, 33, 704-714.

7. Transition metal complexes, see: (a) Grumbine, S. D.; Tilley, T. D.; Arnold, F. P.; Rheingold, A. L. J. Am. Chem. Soc. 1993, 115, 7885; (b) Zybill, C.; Müller, G. Angew. Chem. Int. Ed. 1987, 26, 669-671; (c) Straus, D. A.; Tilley, T. D.; Rheingold, A. L.; Geib, S. J. J. Am. Chem. Soc. 1987, 109, 5872; (d) Waterman, R.; Hayes, P. G.; Tilley, T.D. Acc. Chem. Res. 2007, 40, 712-719.

8. Base-stabilized species, see: (a) Karsch, H. H.; Keller, U.; Gamper, S.; Müller, G. Angew. Chem. Int. Ed. Engl. 1990, 29, 295-296. (b) Takeda, N.; Suzuki, H.; Tokitoh, N.; Okazaki, R. J. Am. Chem. Soc. 1997, 119, 1456-1457.

9. The related acyclic, silylene anion radicals are twocoordinate in both solution and in the solid state. See: Inoue, S.; Ichinohe, M.; Sekiguchi, A. J. Am Chem. Soc. 2007, 129, 6096-6098.

10. (a) Asay, M.; Jones, C.; Driess, M. Chem. Rev. 2o11, 111, 354-396; (b) Gehrhus, B.; Lappert, M. F.; Heinicke, J.; Boese, R.; Bläser, D. J. Chem. Soc., Chem. Commun. 1995, 1931-1932; (c) Lappert, M. F.; Protchenko, A.; Power, P. P.; Seeber, A. Metal Amide Chemistry; John Wiley \& Sons, Ltd: Chichester, UK, 2009, 264-271.

11. Kira, M.; Ishida, S.; Iwamoto, T.; Kabuto, C. J. Am. Chem. Soc. 1999, 121, 9722-9723.

12. (a) Tsutsui, S.; Sakamoto, K.; Kira, M. J. Am. Chem. Soc. 1998, 120, 9955-9956; (b) Takahashi, M.; Tsutsui, S.; Sakamoto, K.; Kira, M.; Müller, T.; Apeloig, Y. J. Am. Chem. Soc. 2001, 123, 347-348.

13. Lee, G.; West. R.; Müller, T. J. Am. Chem. Soc. 2003, $125,8114-8115$.

14. For the synthesis and characterization of 1-4 see the Associated Content.

15. Preparation of $\left(\mathrm{LiSAr}^{\mathrm{Me} 6}\right)_{2}$, see: Ellison, J. J.; Ruhlandt-Senge, K.; Power, P. P. Angew. Chem. Int. Ed. Eng. 1994, 33, 1178-1180.

16. (a) Green, S.P.; Jones, C.; Stasch, A. Science. 2007, 318, 1754-1757; (b) Bonyhady, S. J.; Green, S. P.; Jones, C.; Nembenna, S.; Stasch, A. Angew. Chem. Int. Ed. 2009, 48, 2973-2977. (c) Bonyhady, S. J.; Jones, C.; Sharanappa, N.; Stasch, A.; Edwards, A. J.; McIntyre, G. J.; Chem. Eur. J. 2009, 16, 938.

17. A silylene stabilized by two ylides was isolated using (IMesMg) . See: Asay, M.; Inoue, S.; Driess, M. Angew. Chem. Int. Ed. 2011, 50, 9589-9592.

18. Wiberg, K. Tetrahedron 1968, 24, 1083-1096.
19. Apeloig, Y.; Godleski, S. A.; Heacock, D. J.; McKelvey, J. M. Tetrahedron Lett. 1981, 22, 3297-3300.

20. Oláh, J.; Veszprémi, T.; Woollins, J. D.; Blockhuys, F. Dalton Trans. 2010, 39, 3256-3263.

21. All DFT calculations were carried out using the Turbomole 6.3 program package. (b) TURBOMOLE V6.3 2011, a development of University of Karlsruhe and Forschungszentrum Karlsruhe $\mathrm{GmbH}, 1989-$ 2007, TURBOMOLE GmbH, since 2007; available from http://www.turbomole.com.

22. (a) Perdew, J. P.; Burke, K.; Ernzerhof, M. Phys. Rev. Lett. 1996, 77, 3865-3868; (b) Perdew, J. P.; Burke, K.; Ernzerhof, M. Phys. Rev. Lett. 1997, 78, 1396; (c) Perdew, J. P.; Ernzerhof, M.; Burke, K. J. Chem. Phys. 1996, 105, 9982-9985; (d) Adamo, C.; Barone, V. J. Chem. Phys. 1999, 110, 6158.

23. (a) Weigend, F.; Häser, M.; Patzelt, H.; Ahlrichs, R. Chem. Phys. Lett. 1998, 294, 143-152; (b) Weigend, F.; Ahlrichs, R. Phys. Chem. Phys. 2005, 7, 32973305.

24. Jutzi, P.; Leszczyńska, K.; Neumann, B.; Schoeller, W. W.; Stammler, H. Angew. Chem. Int. Ed. 2oo9, 48, 2596-2599.

25. Jutzi, P.; Mix, A.; Neumann, B.; Rummel, B.; Stammler, H. -G. Chem. Commun. 2oo6, 3519-3521.

26. Apeloig, Y.; Karni, M. J. Chem. Soc., Chem. Commun. 1985, 1048-1049.

27. Known examples of bisthiolatosilanes afford triplet ${ }^{29} \mathrm{Si}$ NMR signals in the range $\delta=-14$ to -19.5 . The corresponding ${ }^{1} \mathrm{H}$ NMR spectra display $\mathrm{Si}-\mathrm{H}$ signals in the range $\delta=4.98-5.10$. See, Fester, G.; Roewer, G.; Kroke, E. Method for the Production of Hydrogen-Rich Silanes, and Novel Chemical Compounds. Eur. Pat. WO2007118474, October 27, 2007.

28. (a) Mitzel, N. W.; Losehand, U. Angew. Chem. Int. Ed. Engl. 1997, 36, 2807-2809. (b) Losehand, U.; Mitzel, N. W. J. Chem. Soc., Dalton Trans. 1998, 2537-2540.

29. (a) Haaf, M.; Schmiedl, A. J.; Schmedake, T. A.; Powell, D. R.; Millevolte, A. J.; Denk, M.; West, R. J. Am. Chem. Soc. 1998, 120, 12714; (b) Haaf, M.; Schmedake, T. A.; Paradise, B. J.; West, R. Can. J. Chem. 200o, 78, 152-15336.

3o. (a) Moedritzer, K.; Van Wazer, J. R. J. Inorg. Nucl. Chem. 1967, 29, 1851-1858. (b) Moedritzer, K. Inorg. Chim. Acta. 1971, 5, 547-553.

31. Ahdab, A. A.-E.; Rima, G.; Gornitzka, H.; Barrau, J. J. Organomet. Chem. 2001, 636, 96-107.

32. Wang, Y.; Ma, J. J. Organomet. Chem. 2oo9, 694, 2567-2575.

33. Please cite preceding paper here. 